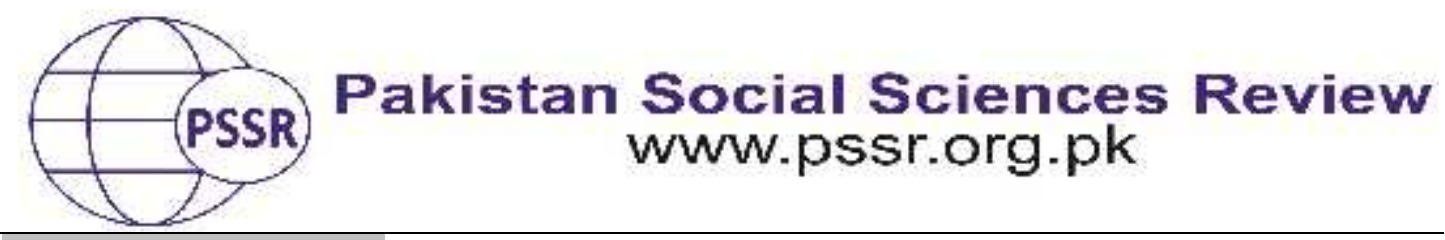

RESEARCH PAPER

\title{
Tolerance, Peace and Social Cohesion among University Students of Pakistan: A Qualitative Assessment
}

\author{
AnilaYasmin ${ }^{1}$ Dr. Muhammad Naeem Ashraf ${ }^{2}$ Nadia Rafique ${ }^{3}$
}

1. Lecturer, Department of Education, Government College for Women PirMahal, Toba Tek Singh, Punjab, Pakistan

2. Assistant Professor, Department of Education, Government Postgraduate College Samundri, Faisalabad, Punjab, Pakistan

3. Headmistress, Government M.C Girls High School, Millat Colony Faisalabad, Punjab, Pakistan

\begin{tabular}{|c|c|}
\hline & BSTRACT \\
\hline & \multirow{11}{*}{$\begin{array}{l}\text { Tolerance, peace and social cohesion are the key predictors for } \\
\text { any sustainable society. The present study explored the factors } \\
\text { affecting lack of tolerance, peace and social adjustment among } \\
\text { university students. A qualitative study investigated various } \\
\text { dimensions of above mentioned variables of interest. The } \\
\text { Participants of study were students and chairpersons of } \\
\text { Government College University Faisalabad. The Focused group } \\
\text { discussion and Semi structured interviews were conducted to } \\
\text { assess the insights and wisdom of participants. The findings of } \\
\text { the study denoted the low level of tolerance regarding its sub } \\
\text { factors; gender, caste, rival ship and social status. The study } \\
\text { also revealed less extent of peace relevant to sub factors; } \\
\text { religion, religious sects, discrimination and ethnic hatred. } \\
\text { Moreover results revealed less degree of social cohesion in } \\
\text { university students. It is strongly recommended to establish } \\
\text { training programs to develop tolerance, peace and social } \\
\text { cohesion through education. }\end{array}$} \\
\hline & \\
\hline & \\
\hline & \\
\hline & \\
\hline Key & \\
\hline Peace, Social & \\
\hline & \\
\hline & \\
\hline Corresponding & \\
\hline Author & \\
\hline
\end{tabular}

\section{Introduction}

Tolerance is an attitude and it is flourished by acceptance of universal human rights and basic freedom of others. It cannot be used to justify the violation of these fundamental values. Changes in values standards and in cultural norms are being encountered by Pakistani society. The cultural troubles of society are at their peak, like jealousy, revenge, frustration, social injustice and racism. Common places in Pakistani society are replete with aggressive, violent and intolerant behavior. The selection of this study is based on while keeping in consideration of the results of these inquiries, the factors of disability, religion, ethnicity and gender have been selected for this study. Religion sects and casts relate our society. People in religious 
minority, racial or particular caste are discriminated and they are given jobs or work of lower or inferior rank. This discrimination is in abundance in Hindus due to minority and lower casts. The investigation on intolerance and tolerance is difficult to keep it away from societal and cultural setting where in they are administered. Primarily education changes the lives of individuals by changing their roles and fundamental beliefs in the way of variety tolerance and devotion to valves that are democratic in nature; it is understood traditionally and dominantly understood. These alterations are due to the developments in students' cognition and personality, not an outcome of simply direct tolerance teaching and democratic ideals. It is believed that education strengthens ego which in turn develops the ability to tolerate diversity.

There is no doubt that there have been very limited researches that are investigating the understanding about causes of peace. But the factors have been investigated which are generally associated with conflict. The section by focusing on the characteristics which can make conflict and the factors which are commonly associated with overviewed of such research. In the world development 2011 report, the World Bank suggested factors and characteristics which are related to justice, security and economy. The drivers of conflict are specific to a given conflict. The accepted indicators are related to the better danger of conflict.

Social cohesion is required substitution for the different factors that caused results in class discrimination, inequalities and ethnicity difference that shatter the power of unity. There are some procedures for these variables. Social turbulence and structural adjustment put their hands to promote social cohesion that may prevail in any society. Social order has its two sub-division; cohesion and conflict. These play important role in building society. Constant of scare resources put a competition between humanity that makes people to live peacefully in any society.

\section{Literature Review}

Albert Hirschman stresses that thought gives a widely acceptable basis and provides ground for tolerance. He further adds that anyone's logical personal benefits can counteract their aggressive and destructive emotions. He affirmed that with controlling the disastrous passions of men, the renaissance conviction and $17^{\text {th }}$ century philosophy and religions dogmas no longer are trusted. The aspirations like lust for power envy for dignity were regarded as troubling and alarming. It is understood that someone's violent passions are not stopped that will lead to conflicted ultimately to social paranoia. The other notion that personal benefits could overpower damaging emotions was thought as a realistic basis for a visible social order: Own interests particularly in the veil of own interests activity are known as quiet, flawless and painless (Hirschman, 2013).

The teaching community like teachers, faculty members and reviewers has diverse thinking methods to teach tolerance and they confront with the idea of teaching tolerance. The presence of diversity must be acknowledged (Stevens 
\&Charles, 2005). College students must be more tolerant because the college graduates and future leaders are considered to be more tolerant because they must have the acquisition of knowledge and competency helped to form behavior because the person is capable of making good adjustment about the social process that help to get the connection between measure and outcomes.

Any nation's heart is, his youth but the whole of the nation is indulged in the ills and evils like corruption, religious extremism, war, violence, mismanagement, due to the presence of these evils of society what would be expected of them. Not only this Pakistani society is divided among ethnic groups, sects, sub sects but cast system and groups also (Masud et al., 2013; Yusuf, 2011). From such a disintegrated and divided society what tolerance can be expected? So, in this way, the values like national ideology constructive thinking, positive mobilization and global competition can only be seen as a dream and push these values into tolerance that gives rise to violence, extremism, aggression and intolerant behavior (Masud et al., 2013) . Now we observe the aggressive attitude of youth by social media against leaders of public and private sector and institutions and all this has happened as modern technology has changed the way of reactions and expressions. It is the failure of society as we analyze the whole situation. The society fails to fill the gap between traditional cultured modern global developments. It's a result of among youth, self-destruction and intolerance increased. The assessment shows that youth is more attracted towards revenge than tolerance. The causes of intolerance may be socio-economic imbalance, culture, media, religion and literacy can be found among possible factors (Abro et al., 2017).

Culture of peace can be attained by peace education; it proves as a pathway and important strategy toward preventing violent conflict. In formal system of education and there working in community based education programs, there is need to educate the educators so that they take the responsibility to serve as change agents who can help transform mindsets, hearts and wills. In building a critical mass of people who will reject violence as resolving conflicts educators are at the heart of the learning process. Educators are also responsible for upholding values of respect for humanity, human dignity, justice, tolerance, interfaith and intercultural understanding and cooperation. The basic purpose of this training is the fundamentals of peace education, its basic knowledge, skills and values that are required to be developed (Castro \& Nario-Galace, 2008).

Walker \& Van der Maesen(2004) has identified four major elements of social excellence i.e. social cohesion, socio-economic status, empowerment and social inclusion. He acknowledges that in these four elements of social mechanism social cohesion as celebrating the major place. He further explains that these four components are fundamentally related to the same purpose of forming identities and self-actualization. Developing a reliable and sound scheme of concept is the major challenge which Foundation has set for itself. 
Social Cohesion defined in the second book of the Foundation (Berman \& Phillips, 2004) describes that it is related to the procedures which are concerned with formulation, securing or destruction of social associations and those social structure which support these associations. Social cohesion is considered appropriate when it facilitates and helps the citizens to be bona fide members of society and to survive as the true human beings. As per (Berman \& Phillips, 2004) history of social cohesion either scientific or political is extended widely. They further state that it is linked with extensive array of other theories and propositions this is why it is very hard to define social cohesion. (Abdullahet al., 2014) also asserts that there is no particular definition of social cohesion. If we have a look on European scene we may observe that there is no clear definition of this term (Pope, 2003). However, increasing interest for cohesion in societies can be observed particularly which has propped up research about cohesion for strengthening public policies necessary for generating constructive environment for European citizens. The explosion of this study sets great challenge for us to discover exact definition of social cohesion for giving it true meaning. It can be said that extensive efforts have been made which lack lucid perception of its theoretical consistency. There are three indicators of social cohesion given by OECD (Healy \& Côté, 2001) which are social cohesion, social capital and social mobility.

\section{Material and Methods}

The qualitative method was used to observe the factors of intolerance, nonexistence of peace and social discharge in students. The students and chairpersons of Government College University were participants in the present study. The focused group discussion and semi structured interview protocol were conducted to conclude results. Focused group discussion with students and interviews with Head of departments assisted the researchers in assessing the direction of the most appropriate factors involved in lack of tolerance, absence of peace and social cohesion.

\section{The Participants}

The sample of focused group discussion was taken through purposive sampling technique. Four sessions having fifty four participants were arranged for focused group discussions. Each session of the focused group discussion was consisted of fifteen participants. Fourteen heads of departments from government college university Faisalabad were also taken to know the opinion regarding existing level of tolerance, peace and social cohesion in students.

\section{Instrumentation}

The exiting literature demonstrated and guided about various dimensions of tolerance, peace and social cohesion for development of instruments. The researchers developed a serious of questions in the light of literature review for focused group discussion and semi structured interview protocol. The questions 
generally addressed and investigated sense of intolerance, absence of peace, social cohesion in university students.

\section{Limitations of Focused Group Discussion}

The objectives of discussion were to

1. Record the perception of students regarding existing level of tolerance, peace and social cohesion

2. Classify the factors involved in decreasing of tolerance, peace and social cohesion among students

3. Asses the need of training program for infusion tolerance, peace and social cohesion in students

\section{Results and Discussion}

\section{Summary of Focused Group Discussion}

\section{Objective \# 1}

\section{Sense of Intolerance among Students}

Participants' revealed extreme concerned about the existing situation of intolerant behavior among university students, they shared several experience which indicated intolerance behavior of their peers and teachers. One of the participants mentioned, "No one is ready to take any action about the intolerant behavior of the university students, I have reported to the authorities but administration pays no attention to these matters so students do not bother to report". He further added that situation could escalate such practice into more serious condition when it remained unaddressed for a long period.

\section{Absence of Peace}

Majority of the participants expressed that there was environment of peace in the university, no bomb explosion, terrorist never attacked this university. Actually they have limited concept of peace in their minds. The researcher explained the value of peace in her introduction which was presented at the beginning of the focused group discussion but it was observed that researcher failed to clear real picture of peace. The researcher revised her trial and became successful at that time. After realizing the concept of peace such as freedom of disturbance, lawlessness and violence in society, the participants showed their deep concern about absence of peace in society. They indicated many incidents involved disturbance in their personal, social, emotional and academic life. 


\section{Cooperation with each Other}

Participants were highly negative when they were talking about sense of cooperation with each other. A female participant highlighted hopelessly, "We are less concerned with each other as my mates prepare their portfolio but hesitant to share their assignment with me as I will copy their material". A male participant expressed, "The female students has no knowledge and sharing practices, they never share their notes to male students moreover they never cooperate in outdoor activities".

\section{Objective\# 2}

\section{Common Issues}

The participant discussed about various issues which commonly lose their temper and lead towards intolerant behavior or violence in some conditions, they highlighted rivalry at the top of the list while discussing different issues related to intolerant behavior. One of the male participants indicated "I get extremely aggressive when my classmate mingles with other male students which are intolerable for me. One female participant added "I lose my temper if my friend even talks to other; I am possessive about my friends". Participants also pointed out about discrimination among students in university which extremely irritate them a male participant expressed, "female students are always preferred by male teachers and they get more favor from them". He further adds, "Female teachers also give priority to female students" on the other hand most of the female participants highlighted "we are the victim of jealousy by our male classmates, we are more hardworking than male classmates".

\section{Concerning Issues for the Infusion of Tolerance}

After detailed discussion, participants highlighted most specific factors which contributed to the situation of intolerance among university students. Participant generally agreed that religious sects, social status, language and caste system in society contributed towards conflicts among students. A participant from law department potentially pointed out, "There is discrimination on the basis of caste, students develop their relation among their own caste and sometimes I feel myself isolated as a result of caste system". Another participant of the focused group discussion motioned, "being the resident of rural culture when I enrolled myself in the university then I moved to urban area very first time in life, my classmates takes me as less cultured and illmannered as they feel proud of being citizen of urban area. This practice really hearts me".

\section{Key Factors Contributing Absence of Peace}

The students enlisted many factors which generally result absence of peace in society such as mistrust, religious extremism, torture and violence. Some participants shared their personal experiences which caused severe conflicts among university students. A male participant shared the experience of his best friend, "My best friend was emotionally attached with her class fellow, after break up, her class 
fellow tried to blackmail him by various tactics, eventually this situation converted towards major conflict between two students groups which caused physical torture among students".

\section{Social Adjustment in Universities}

The Participants were moderately positive regarding social adjustment. According to their perception non cooperative behavior was promoting in universities. Educational institutions are the reflection of the society and Pakistani society has a lack of social cohesion which ultimately affects the lives of our students in universities. A female participant stated, "The male students are cooperative with each other's but less cooperative with female students". On the other hand a male participant contradicted with her point of view by adding, "The female students never share their ideas, notes and learning practices with them". The researchers observed that gender of students, male and female were divided over this point and there were feelings of rival ship and jealousy between them. One of the female participants expressed with sorrow, "We receive unwelcoming sexual gestures and remarks while walking in the university which really irritate us, ultimately we create a distance with male students and do not cooperate with them, she further adds, "It is very difficult to be a women in this men dominated complex society". A male participant defended his position and said, "We are also victim of unwanted gestures form our university fellows, female students never proved trustworthy and loyal, they cannot keep any secrets so we intentionally never share our learning problems to them".

\section{Objective\# 3}

\section{Developing Tolerance, Peace and Social Cohesion among University students}

The Participants failed to present suggestions regarding the development of tolerance, peace and social cohesion among university students. One of the participants said hopelessly, "Social cohesion cannot be developed, we are living in noncooperative and intolerant society so it is very hard to create conducive learning environment in universities, we are self-centered and selfish", she adds. Another participant disagreed and said, "We should not lose hope, we can develop tolerance, peace and social cohesion through education and education is the key of social modification. One of the respondents floated his idea by adding, "Mutual cooperation among society can be developed through the positive use of social and electronic media". A female participant concluded the discussion by suggesting that there is need of awareness regarding benefits of tolerance, peace and social cohesion to university students and it can be achieved through education.

\section{Summary of Interviews}

Head of departments from Government College University Faisalabad were interviewed because they were directly associated with student affairs and they were the keen observer of students behavior regarding intolerance, absence of peace and lack of social cohesion. The objectives of using in-depth interview are to 
determine the factors involved in the present study. In-depth interview covered following main objectives:

1 The perception of Head of Departments regarding existing situation of tolerance, peace and social cohesion

2 Identification symptoms of intolerance, absence of peace and lack of social cohesion

3 The factors affecting tolerance, peace and social cohesion among university students

Table

Themes and Sub-themes of Interviews with Head of Departments

\begin{tabular}{|c|c|c|}
\hline Objectives & Themes & hemes \\
\hline $\begin{array}{l}\text { Perception of } \\
\text { university } \\
\text { A HOD,s } \\
\text { regarding } \\
\text { existing leve] } \\
\text { of tolerance, } \\
\text { peace and } \\
\text { social cohesion }\end{array}$ & $\begin{array}{l}\text { (i) Intolerance } \\
\text { behavior } \\
\text { (ii) Absence of } \\
\text { peace } \\
\text { (iii) Lack of social } \\
\text { cohesion }\end{array}$ & $\begin{array}{l}\text { (i) Sense of } \\
\text { intolerance among } \\
\text { university students } \\
\text { (ii) Situation created } \\
\text { by absence of peace } \\
\text { (iii) How lack of social } \\
\text { cohesion leads towards } \\
\text { disarrangements }\end{array}$ \\
\hline $\begin{array}{l}\text { Symptoms of } \\
\text { B intolerance, } \\
\text { absence of } \\
\text { peace and lack } \\
\text { of Social } \\
\text { Cohesion }\end{array}$ & $\begin{array}{l}\text { Symptoms of intolerance, } \\
\text { absence of peace and lack of } \\
\text { of Social Cohesion } \\
\text { a } \\
\text { al }\end{array}$ & 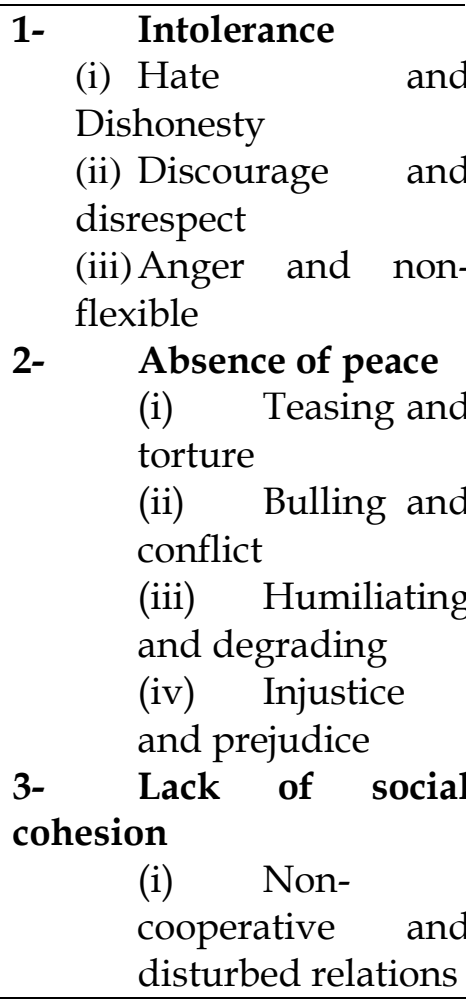 \\
\hline
\end{tabular}


(ii) Isolation

and exclusion

(iii) Non-

involvement and

rejection

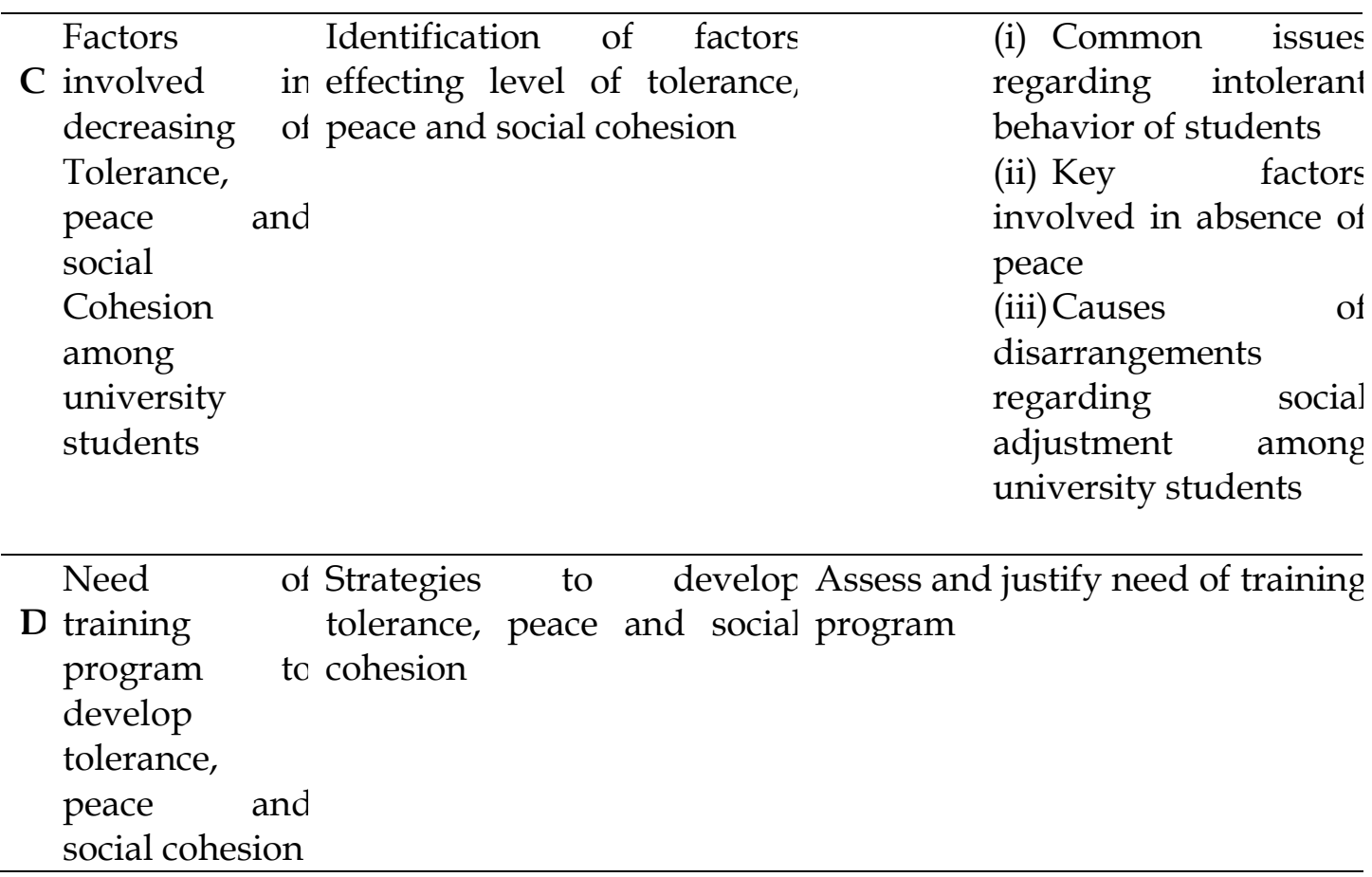

\section{Level of Tolerance, Peace and Social Cohesion}

The opening discussion point was to get the overview of participants regarding the existing level of tolerance, peace and social cohesion in the university students. The objective of the discussion was to sought opinions and observations of head of departments about the incidents of torture and violence in university setting. Interviews with head of departments revealed their several experiences and observations regarding the intolerance, absence of peace and lack of social cohesion among university students. First category was divided into three sub categories, (i) sense of intolerance, (ii) Situation created by absence of peace, (iii) How lack of social cohesion leads towards disarrangements among university students.

\section{Sense of Intolerance}

All respondents showed great concern about the intolerant behavior of university students. They were of the view, "intolerance is prevailing everywhere in society and students are also part of this society, when they come to university they even get hyper on the minor things. They become aggressive, they are not willing to tolerate the opinions of others and sometimes this situation leads towards conflict and violence". The respondents raised the voice, "University students unable to solve their minor problems 
with mutual cooperation and understandings and they demonstrate their anger and protest consequently such things show extremely intolerant behavior". The respondents were agreed that university students were getting violent and aggressive with passage of time. One respondent mentioned with grief, "Many students as well as teachers were the victim of intolerant behavior, Students were physically tortured even murdered on minor issues, teachers were kidnapped and they were physically tortured by some violent groups of students in the university".

\section{Situation of Peace}

The respondents were worried that intolerant behavior of students drives toward conflict and violent practices in university students. They mentioned, "Intolerant behavior give birth to absence of peace in the minds of students, they try to handle their problems and issues with force so eventually this situation disturb educational environment". The respondents were anxious that violent students indulge themselves in unlawful activities. One of the respondent mentioned, "I teach law to the students and try to develop respect of rules and regulations in students but I noticed the most of the students do not pay attention to my words as they think that there is no respect of obedience to law in society".

\section{Social Cohesion in University Students}

Majority of respondents indicated that intolerant behavior and absence of peace direct toward social disarrangements in students. They added, "There is a lack of social adjustment in our society and educational institutions are the part of that society so effects of social disintegration are also visible in our students". They further mentioned that they were the close observer of the students and they could paint the real picture of social disarrangements among university students. Respondents were strongly agreed and they mentioned, "There is lack of collaborative learning, students do not work in groups to complete their tasks furthermore there is lack of trust and are unable to establish good relations".

\section{Symptoms of Intolerance, absence of Peace and lack of Social Cohesion}

The respondents also elaborated many symptoms of intolerant behavior, absence of peace and lack of social cohesion in students. While talking about intolerant behavior they mentioned, "The students display anger and hate in their attitudes towards different things which they like or dislike. In some situations they do not respect the university rules and regulations; non-flexibility in their behavior has also been observed and sometimes they get violent to solve their problems". The respondent mentioned the conditions regarding absence of peace in university students. They reported, "The students exercise violent practices, they indulge themselves in unlawful activities, their intolerant behavior leads them towards major conflicts". As for as lack of social cohesion is concerned, the respondents mentioned, "The students do not enjoy healthy social relation with each other's, they feel hesitate to cooperative with each other's 
moreover some students isolate themselves from their peers and do not adjust in university environment".

\section{Identification of Factors affecting level of Tolerance, Peace and Social Cohesion}

The second discussion point was the identification of factors effecting level of tolerance, peace and social cohesion among students. The objective of this discussion section was to explore the causes of intolerant behavior, absence of peace and lack of social cohesion among university students. The researchers were anxious to explore that why students get violent, they protest against administration and why they take extreme steps such as torture, kidnapping and even killing to others. The researchers were also interested to know the reasons that why students were not socially connected.

\section{Factors affecting Intolerance}

Respondents indicated factors like gender caste rival ship and social status which directly affected the level tolerance among students. Majority of the respondents mentioned, "Our society discriminates male and female on the basis of gender, women do not enjoy equal rights as compared to men moreover women are also kept deprive from education". They mentioned, "People's attitude about women education is negative, they think that women should only perform household duties, they are not ready to accept the modern trends towards women education". One of the respondents further added, "Male students become aggressive due to given more attention to female students by teachers in universities".

The respondents mentioned rival ship as one of the important factors which contribute towards intolerance in students. They further elaborated, "Many incidents are reported that students get hyper to due rival ship and they take extreme steps such as kidnapping torture and even murder due to rivalry feelings about their class mates". One of the respondents mentioned, "Students are much possessive about their emotional relationships, at Government College University Faisalabad three murder cases has been reported within the span of one year on account of rivalry feelings of love". He further adds that emotional blackmailing of students leads towards major conflicts.

The respondents told the researchers that students get divided into groups over caste and such division is also cause of intolerant behavior as they develop their pressure groups on the basis of race. They mentioned, "Friendship is established on the basis of caste in universities and the students who think that they belong to superior caste are not willing to tolerate other students and they used to humiliate them." They further suggest, "There is need to learn that every human being is equal and respectable, teachers should play their vital role to eliminate these biases and promote love for humanity through education". 


\section{Factors affecting Peace}

The respondents raised many points when they spoke about absence of peace in university context. They elaborated that religious sect; religious extremism, discrimination and ethnic haltered were major factors which created unrest in the minds of students and eventually that situation lead towards absence of peace. The respondents shared, "In Pakistan the people are much emotional about their religious beliefs and they are also divided on the basis of sect, there are religious extremist who mislead the people on the name of Islam for the accomplishments their evil designs. Universities present the reflection of the society and unlawful practices are also visible in educational institutions as students divide over religious sects which raise the maximum chances of conflicts". They potentially supported that universities should develop programs to teach respect for humanity through education.

The respondents pointed out that teachers discriminate the students on the basis of gender, caste, language and social status and such unfair conduct created unrest in university students. The students get annoyed due to discriminatory behavior and they violate rules and regulations. Sometimes these circumstances move towards severe conflicts and disturb the peaceful environment in universities. The respondents mentioned, "The female students get special favor over male students by teachers, in some situations the teachers favor the students due to high social status. This improper behavior creates aggression in students as a result such thing sabotage environment of peace".

\section{Factors affecting Social Cohesion}

The respondents indicated various causes of low social adjustments among university students such as diversity, recognition belongingness mistrust and harassment. The respondents mentioned, "Intolerant behavior and absence of peace lead towards lack of social cohesion in university students. Some students develop emotional ties with each other's and when these relations breakup they get emotionally disturbed. They become isolated in their social life." The respondents reported, "Students do not adjust themselves in co-education, there is a lack of coordination between male and female students. However Female students mention that they receive unwanted gesture by university fellows so they hesitate to establish relation with them."

\section{Strategies to Develop Tolerance, Peace and Social Cohesion}

Last question of inquiry was how tolerance, peace and social cohesion can be developed in university students. The respondents viewed, "tolerance, peace and social cohesion are the fundamental values of society and universities can play their vital role to promote such values in the students through education." They recommended strongly that universities should take initiative to impart content of tolerance, peace and social cohesion in curriculum, organize awareness seminars and develop training programs to infuse tolerance, peace and social cohesion among university students. 


\section{Conclusion and Recommendations}

The Participants of focused group discussion were extreme concerned about the existing situation of intolerant behavior among students, they shared experiences which indicated intolerance behavior of their peers and teachers. The participants showed their deep concerns about absence of peace, lawlessness and violence in society. They indicated many incidents involved disturbance in their personal, social, emotional and academic life.TheParticipants were highly unenthusiastic when they were talking about lack of cooperation with each other. They potentially exposed that discrimination among students in university which extremely irritate them. They were generally agreed that religious sects, social status, language and caste system in society contributed towards conflicts among students. Moreover they were also irritated to see prevailing situation of religious extremism, torture and violence, Educational institutions are the reflection of the society and Pakistani society has a lack of social cohesion which ultimately affected the lives of our students in universities.

The respondents of interview protocol were worried that intolerant behavior drives towards conflict and violent practices in university students. They potentially mentioned that intolerant behavior give birth to absence of peace in the minds of students moreover they try to handle their problems and issues with force eventually this situation disturb educational environment. The respondents were anxious that violent students indulge themselves in unlawful activities.

Head of departments indicated that intolerant behavior and absence of peace direct towards social disarrangements in university students. They further added that there is a lack of social adjustments in our society however educational institutions are the part of that society so effects of social disintegration are also visible in our students. Respondents indicated factors like gender, caste, rival ship and social status which directly affected the level tolerance among students. Majority of the respondents mentioned that their society discriminates male and female on the basis of gender, women did not enjoy equal rights as compared to men and they were also kept deprive from education.

The religious sect, religious extremism, discrimination and ethnic haltered are major factors which create unrest in the minds of students and eventually this situation leads towards absence of peace. They potentially supported that university should develop programs to teach respect for humanity through education. The discrimination on the basis of gender, caste, language and social status created unrest among students. The Intolerant behavior and absence of peace lead towards lack of social cohesion among students. The study suggested that there is need of training sessions to develop tolerance, peace and social cohesion in students. University administrations should plan comprehensive training programs for the development of such fundamental virtues in students. 


\section{References}

Abdullah, A., Marzbali, M. H., Woolley, H., Bahauddin, A., \& Maliki, N. Z. (2014). Testing for individual factors for the fear of crime using a multiple indicatormultiple cause model. European Journal on Criminal Policy and Research, 20(1), 122.

Abro, A. A., Fateh, A., \& Saeed, N. (2017). Intolerance Among Youth And Its Impacts On Pakistani Society: Sociological Analysis Of Urban Sindh. Grassroots, 51(1).

Berman, Y., \& Phillips, D. (2004).Indicators for social cohesion. Paper submitted to the European Network on Indicators of Social Quality of the European Foundation on Social Quality, Amsterdam.

Castro, L. N.-C., \& Nario-Galace, J. (2008).Peace education: A pathway to a culture of peace: Center for Peace Education, Miriam College.

Healy, T., \& Côté, S. (2001).OECD.The Well-Being of Nations. The Role of Human and Social Capital: Paris.

Hirschman, A. O. (2013). The passions and the interests: Political arguments for capitalism before its triumph: Princeton University Press.

Masud, M., Ahmed, H., Choudhury, A. H., \& Mostafa, M. R. (2013). Pakistan: On the way to be Failed state. Mediterranean Journal of Social sciences, 4(1), 63-70.

Pope, J. (2003). Social capital and social capital indicators: A reading list: Public Health Information Development Unit [for the] Commonwealth Department of Health and Ageing.

Stevens, R., \& Charles, J. (2005).Preparing teachers to teach tolerance. Multicultural Perspectives, 7(1), 17-25.

Walker, A., \& Van der Maesen, L. (2004). Social quality and quality of life Challenges for quality of life in the contemporary world (pp. 13-31): Springer.

Yusuf, M. (2011). A society on the precipice? examining the prospects of Youth radicalization in Pakistan. In K. Michael \& R. M. Hathaway (Eds.), Reaping the dividend(pp. 76-105). Washington, DC: Woodrow Wilson International Center for scholars. 